\title{
IMPLEMENTATION TELEGRAM CHAT BOT ON STUDENT ORIENTATION PERIOD REGISTRATION SYSTEM FOR EFFICIENCY OF DATA MANAGEMENT
}

\author{
Faris Zaky Alfaiz ${ }^{* 1}$, Maryam² \\ ${ }^{1,2}$ Informatika, Fakultas Komunikasi dan Informatika, Universitas Muhammadiyah Surakarta, Indonesia \\ Email: ${ }^{1} \underline{1200160077 @ \text { student.ums.ac.id, }}{ }^{2} \underline{\text { mar290@ums.ac.id }}$
}

(Naskah masuk: 15 Januari 2021, diterima untuk diterbitkan: 22 Januari 2021)

\begin{abstract}
Orientation is a routine activity carried out by both public and private tertiary institutions. Universitas Muhammadiyah Surakarta (UMS) which is a private higher education institution also has several types of orientation, one of which is thePeriod of Ta'aruf the Muhammadiyah Student Association (MASTA IMM). IMM. IMM MASTA implementation that has occurred so far in the data processing process is still done manually, so there is often the same data and the time to manage the data is less effective and efficient. This study aims to design a MASTA IMM registration system using Telegram bot to simplify and streamline time in data management and class division. The method used in this research is themethod Waterfall modified, where the repair process is carried out only after the testing and evaluation stages. The development of this system will use the Telegram Bot API and theprogramming Pythonlanguage by utilizing library the provided. This system has several functions, including registration, adding and deleting data, dividing classes, and printing data intodocuments excel. This system has also been tested with good results. The test method used is the blackbox to find out the functionality of the system running properly. As well as testing the System Usability Scale (SUS) to evaluate the usefulness of the system with a final average result of 76.33, which means that the user agrees with the system that has been designed. This system is able to provide convenience during student registration and make it easier for admin in data management.
\end{abstract}

Keywords: telegram bot, python, MASTA IMM.

\section{IMPLEMENTASI TELEGRAM CHAT BOT PADA SISTEM PENDAFTARAN MASA ORIENTASI MAHASISWA GUNA EFISIENSI PENGELOLAAN DATA}

\begin{abstract}
Abstrak
Orientasi merupakan kegiatan rutin yang dilaksanakan oleh instansi Perguruan Tinggi baik itu negeri maupun swasta. Universitas Muhammadiyah Surakarta (UMS) yang merupakan Lembaga Pendidikan Tinggi Swasta juga memiliki beberapa jenis orientasi, salah satunya adalah Masa Ta'aruf Ikatan Mahasiswa Muhammadiyah (MASTA IMM). IMM. Pelaksanaan MASTA IMM yang terjadi selama ini dalam proses pengolahan datanya masih dilakukan secara manual, sehingga sering terjadi adanya data yang sama dan waktu untuk mengelola datanya kurang efektif dan efisien. Penelitian ini bertujuan untuk merancang sistem pendaftaran MASTA IMM menggunakan Telegram bot untuk mempermudah dan mengefisienkan waktu dalam pengelolaan data dan pembagian kelas. Metode yang digunakan dalam penelitian ini adalah metode Waterfall yang telah dimodifikasi, di mana proses perbaikan dilakukan hanya setelah tahap pengujian dan evaluasi. Pengembangan sistem ini akan menggunakan Telegram Bot API dan bahasa pemrograman Python dengan memanfaatkan library yang telah disediakan. Sistem ini memiliki beberapa fungsi, di antaranya yaitu pendaftaran, menambahkan dan menghapus data, membagi kelas, dan mencetak data ke dalam dokumen excel. Sistem ini juga telah melewati pengujian dengan hasil yang baik. Metode pengujian yang digunakan adalah blackbox untuk mengetahui fungsionalitas sistem berjalan sesuai dengan semestinya. Serta pengujian System Usability Scale (SUS) untuk mengevaluasi kegunaan sistem dengan hasil rata-rata akhir 76,33 yang berarti user menyetujui sistem yang telah dirancang. Sistem ini mampu memberikan kemudahan saat pendaftaran mahasiswa serta mempermudah admin dalam pengelolaan data.
\end{abstract}

Kata kunci: telegram bot, python, MASTA IMM.

\section{PENDAHULUAN}

Orientasi mahasiswa baru merupakan kegiatan rutin yang dilaksanakan oleh instansi Perguruan
Tinggi, tak terkecuali oleh Universitas Muhammadiyah Surakarta (UMS). Pelaksanaan orientasi dilaksanakan di setiap awal tahun ajaran 
baru sebagai proses pengenalan mahasiswa dengan lingkungan Perguruan Tinggi.

UMS sendiri memiliki beberapa jenis orientasi, salah satunya ialah Masa Ta'aruf Ikatan Mahasiswa Muhammadiyah (MASTA IMM) yang dilaksanakan oleh Ikatan Mahasiswa Muhammadiyah (IMM) dengan tujuan untuk mengenalkan organisasi mahasiswa Islam yang ada di UMS sekaligus mengenalkan Muhammadiyah sebagai organisasi Islam yang menaungi IMM dan UMS.

Proses pelaksanaan MASTA IMM yang terjadi selama ini, terkhusus pada saat pendaftaran hingga menjelang pelaksanaannya meliputi pembagian kelas dan pembuatan absen masih menggunakan proses manual. Hal tersebut sering kali menimbulkan adanya redundansi data serta penggunaan waktu yang tidak efisien. Proses pendaftaran dapat dilakukan secara langsung maupun secara online dengan memanfaatkan Google Formulir.

Pemanfaatan Google Formulir sebagai sarana pendaftaran telah diimplementasikan dalam Pemanfaatan Google Formulir Sebagai Sistem Pendaftaran Anggota Pada Website Aptisi.or.id di mana Asosiasi Perguruan Tinggi Swasta Indonesia belum memiliki sistem pendaftaran secara online dan masih menggunakan berkas berupa formulir cetak. Hal ini dirasa tidak efektif karena menyebabkan berkas yang menumpuk. Manfaat dari penelitian ini adalah untuk meningkatkan efektivitas dan efisiensi dalam pengelolaan data dan pendaftaran yang sebelumnya dilakukan secara konvensional [1].

Penggunaan aplikasi chatting saat ini begitu banyak, tidak hanya untuk komunikasi pribadi, namun juga komunikasi kelompok [2]. Salah satu penggunaannya pernah dikembangkan berupa Perancangan Aplikasi Chatting Berbasis Web di PT. Pura Barutama Kudus menggunakan Socket.IO dan Framework Foundation. Aplikasi tersebut dibuat untuk mengatasi masalah yang terjadi dalam aktivitas komunikasi dan penyebaran informasi yang terjadi selama ini menggunakan layanan email maupun aplikasi messenger yang akan terkendala saat koneksi internet terputus. Manfaat dari aplikasi ini adalah meningkatkan produktivitas dan efisiensi dalam komunikasi dan media penyebaran informasi serta pengiriman berkas [3].

Telegram merupakan aplikasi berkirim pesan instan sumber terbuka (open-source) yang memberikan kebebasan kepada penggunanya untuk mengembangkan kode sumber (source code) dari aplikasi tersebut. Selain itu juga, kelebihan dari Telegram dibanding aplikasi pesan instan lain seperti WhatsApp adalah dukungan bot, berbasis cloud, edit pesan yang telah dikirim, open API, grup publik yang mampu menampung hingga 200.000 anggota, login di banyak perangkat, dan terdapat juga fitur saluran yang di sediakan secara default oleh aplikasi Telegram yang berguna untuk berbagi informasi berupa pesan broadcast kepada pelanggan saluran tersebut [4], [5].
Bot Telegram telah dimanfaatkan dalam berbagai bidang, mulai dari bidang pendidikan, yaitu Otomatisasi Layanan Dan Informasi Mahasiswa dengan kelebihan yang dimilikinya adalah memberikan kemudahan pelayanan dan akses informasi kampus [6], Kuis-Master menggunakan Pesan Online dengan keunggulan berupa pengumpulan data otomatis yang memberikan pertanyaan kuis kepada user [7], dan Aplikasi Kuesioner Evaluasi Belajar [8].

Berdasar keuntungan yang didapatkan dari penelitian sebelumnya, dibuatlah sebuah sistem pendaftaran yang memanfaatkan aplikasi online chatting dan bot sebagai platform pendaftaran MASTA IMM yang berada di UMS. Sistem ini diharapkan mampu mempermudah calon peserta dalam melakukan proses pendaftaran, mempermudah panitia untuk mengelola data calon peserta, dan akan mempermudah Koordinator Komisariat untuk memantau perkembangan jumlah peserta MASTA IMM dan melakukan pengawalan serta pelaporan dari kegiatan tersebut.

\section{METODE PENELITIAN}

Metodologi digunakan dalam penelitian ini adalah Software Development Life Cycle dengan model Waterfall yang telah dimodifikasi [9], dimana proses perbaikan hanya akan dilakukan setelah melalui tahap pengujian dan evaluasi. Diagram metode penelitian pada Gambar 1 .

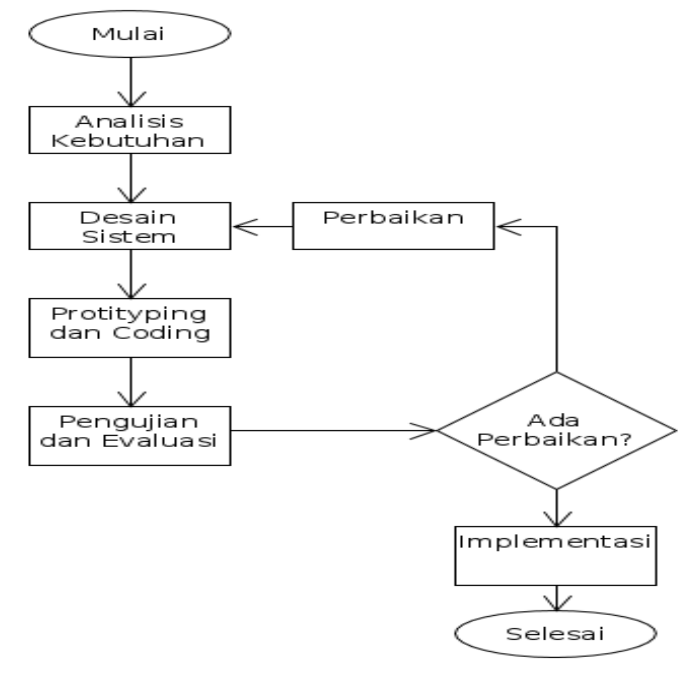

Gambar 1. Diagram Metode Penelitian

\subsection{Analisis Kebutuhan}

Tahap ini diperlukan untuk memahami kebutuhan user dan sangat penting untuk keberhasilan sistem yang interaktif [10]. Kebutuhan dikumpulkan mulai dari pemahaman menyeluruh tentang kebutuhan dan persyaratan user serta hasil dari interaksi melalui wawancara dari hasil evaluasi pelaksanaan MASTA IMM tahun 2019 [10], [11]. Data yang dikumpulkan berupa kendala yang ditemui 
selama persiapan dan proses pendaftaran, koordinasi antara KORKOM IMM UMS dan Komisariat IMM di UMS, hingga pada proses pembagian kelas yang masih dilakukan secara manual. Dari analisis tersebut, disimpulkan adanya kebutuhan fungsional dan non-fungsional pada Tabel 1.

Tabel 1. Kebutuhan fungsional dan non-fungsional

\begin{tabular}{|c|c|}
\hline Kebutuhan fungsional & Kebutuhan non-fungsional \\
\hline 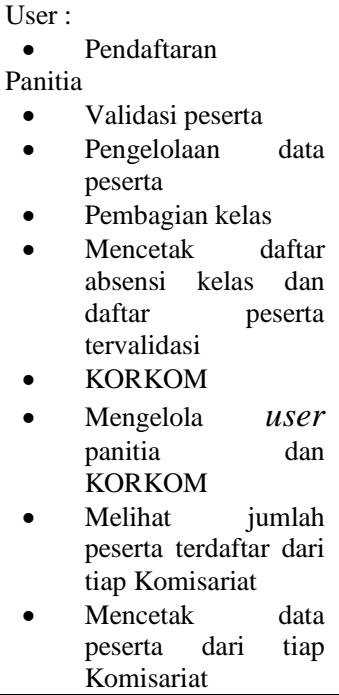 & $\begin{array}{ll}\text { - } & \text { Komputer } \\
& \text { Smartphone } \\
& \text { (Android/IOS) } \\
\text { - } & \text { Internet } \\
\text { - } & \text { Aplikasi Telegram }\end{array}$ \\
\hline
\end{tabular}

\subsubsection{Desain}

Sistem yang akan dibuat pada penelitian ini adalah bot Telegram sebagai pengganti formulir pendaftaran yang dibangun menggunakan bahasa pemrograman Pyhton. Script bahasa pemrograman Python digunakan untuk menangkap perintah dan masukan yang dikirimkan oleh user berupa kata kunci yang telah disediakan oleh sistem yang kemudian akan diidentifikasi oleh program untuk menjalankan fungsi program.

\subsubsection{Use Case Diagram}

Sistem ini memiliki 2 jenis bot, yaitu pendaftaran yang dapat diakses oleh user yang merupakan calon peserta MASTA IMM dan bot admin yang dapat diakses oleh 2 tipe user, yaitu panitia dan KORKOM. Tipe user panitia dioperasikan oleh Pimpinan Komisariat (PK). Use Case Diagram pada Gambar 2 mengenai aktivitas masing-masing user kepada sistem.

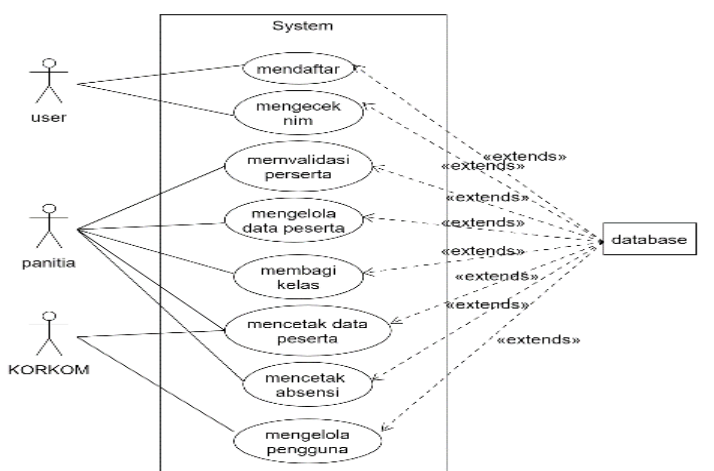

Gambar 2. menjelaskan mengenai aktivitas dari tiap user. Tugas yang dimiliki oleh tiap user didasarkan pada kebutuhan pada Tabel 1. Dimana user hanya dapat melakukan pendaftaran dan panitia mampu melakukan validasi data peserta, memperbaiki data peserta, dan melakukan pembagian kelas. Sedangkan KORKOM mampu mengelola data akun, komisariat, fakultas, dan program studi.

\subsubsection{Activity Diagram}

Activity Diagram menggambarkan langkahlangkah sebuah aktivitas menjalankan prosesnya secara runtut dari awal hingga akhir [12].

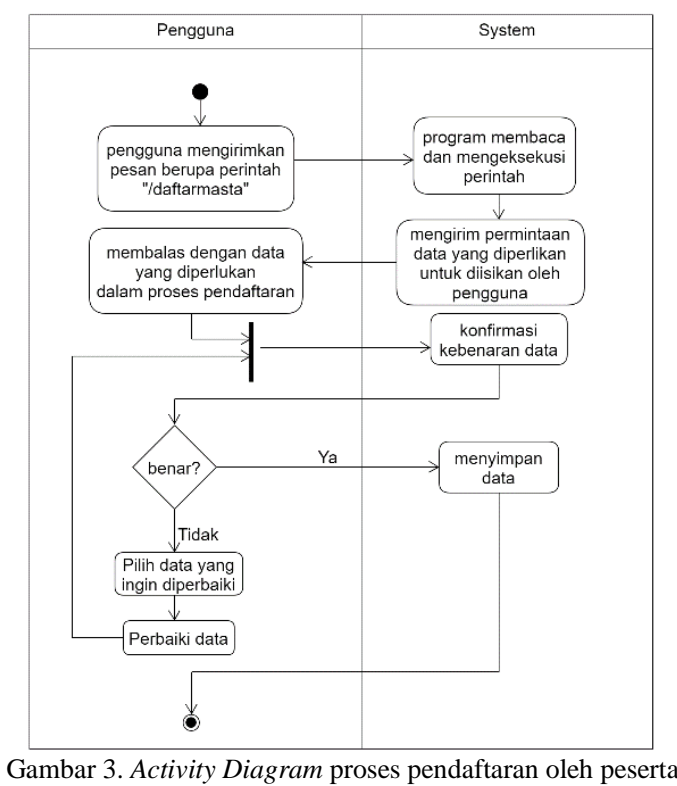

Gambar 3. menunjukkan proses yang terjadi dalam aktivitas pendaftaran yang dilakukan oleh user umum. User mengimkan perintah yang telah disediakan oleh sistem, dan sistem akan menjalankan program sesuai dengan perintah yang telah terdaftar dengan meminta data kepada iser dan kemudian akan menyimpan data tersebut ke dalam database.

Gambar 4 (a). menjelaskan proses yang terjadi dalam aktivitas validasi yang dilakukan oleh PK IMM dengan mengirimkan perintah validasi. Sistem akan meminta NIM peserta yang akan divalidasi, kemudian sistem akan mengirimkan data peserta kepada panitia dan akan mengubah status validasi peserta jika data tersebut benar. Sedangkan Gambar 4 (b). pembagian kelas dari perintah “/bagi_kelas" yang dikirimkan PK ke bot admin. Selanjutnya sistem akan melakukan perhitungan dan mengelompokkan peserta berdasar jumlah yang telah dikirimkan.

Entity Relationship Diagram merupakan gambaran hubungan data antar tabel yang terdapat di dalam suatu database. Rancangan database dari sistem ini terdapat pada Gambar 5. dimana sisem ini memiliki 5 tabel yang saling terhubung. 


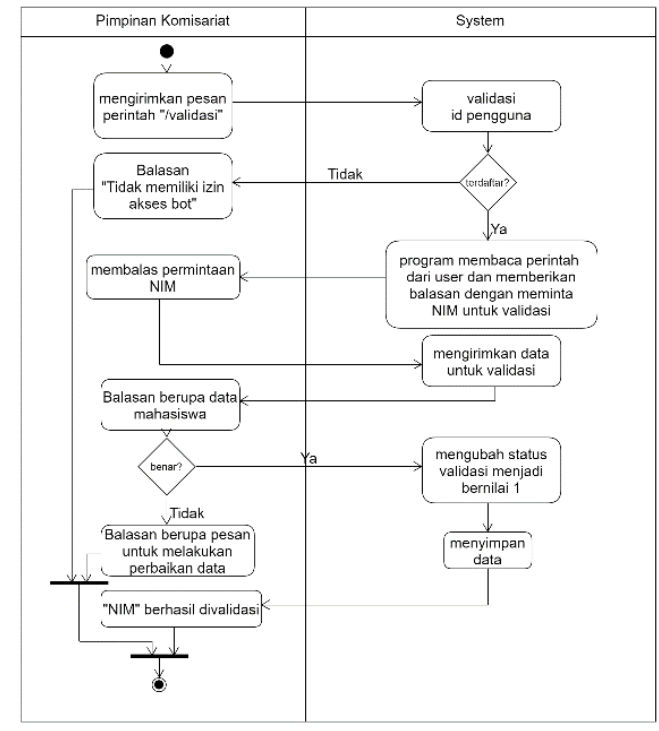

(a)

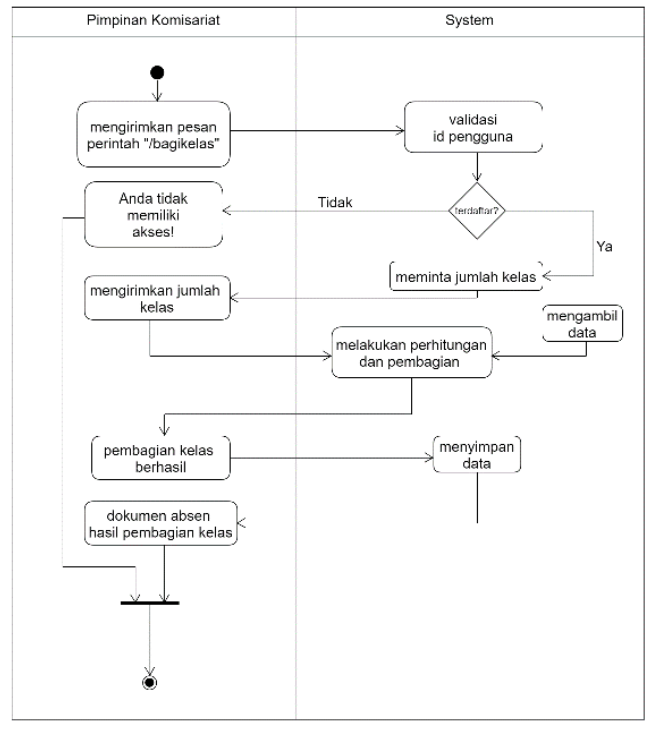

(b)

Gambar 4. Activity Diagram proses (a) validasi oleh PK IMM dan (b) pembagian kelas oleh PK IMM

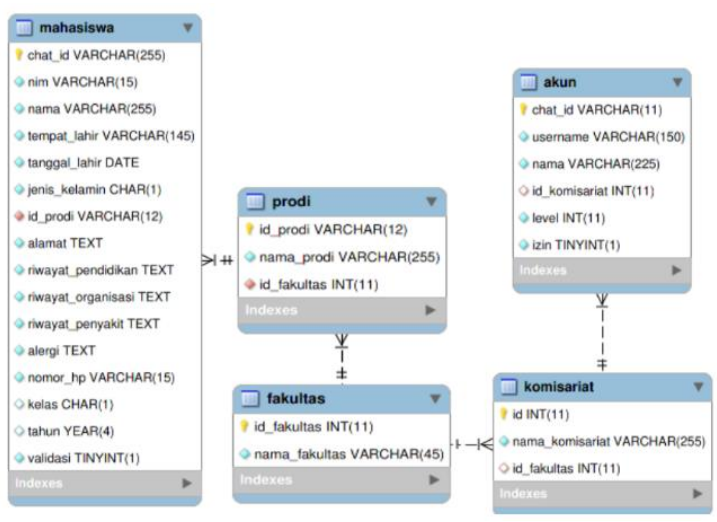

Gambar 5. Entity Relationship Diagram bot Pendaftaran MASTA IMM

\subsection{Prototyping dan Coding}

Tahap ini, merupakan tahapan utama dalam proses perancangan sistem informasi pendaftaran MASTA IMM menggunakan Telegram bot API. Kebutuhan pengembangan bot ini terdapat pada Tabel 2.

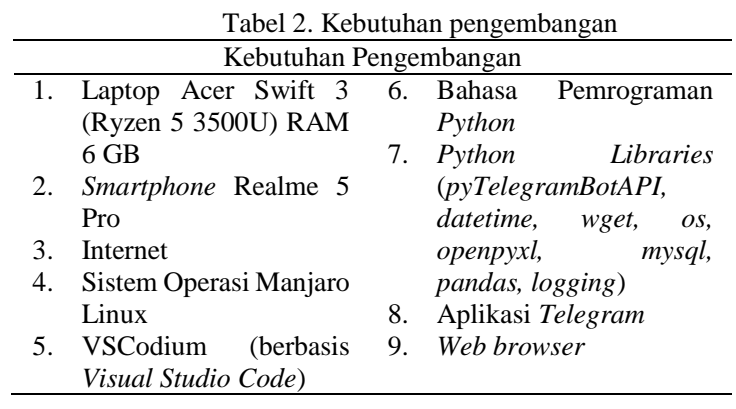

\subsection{Pengujian dan Evaluasi}

Setelah tahap prototyping dilakukan tahapan pengujian untuk melakukan validasi dari fungsional sistem (blackbox testing) di mana pengujian ini lebih terkonsentrasi pada apa yang dilakukan perangkat lunak[13]. Parameter keberhasilan menggunakan kuesioner dengan metode System Usability Scale (SUS) secara online yang akan diisi oleh penguji (tester) dari perwakilan PK IMM yang ada di UMS. SUS merupakan kuesioner standar yang dirancang untuk menilai kegunaan yang dirasakan dari suatu sistem[14].

\subsection{Perbaikan}

Berdasarkan umpan balik dari penguji (tester), jika terjadi kesalahan atau kegagalan sistem dalam menjalankan fungsinya, maka akan dilakukan perbaikan. Sistem ini akan dijalankan di komputer server sebagai service, sehingga program akan berjalan otomatis sesaat setelah server melakukan booting Sistem Operasi.

\subsection{Implementasi}

Sistem ini dapat diimplementasikan pada sebuah komputer server fisik maupun server virtual. Kebutuhan yang diperlukan pada komputer server untuk menjalankan sistem ini adalah bahasa pemrograman Python, databse MySQL, dan Python libraries yang terdapat pada Tabel 2.

\section{HASIL DAN PEMBAHASAN}

Penelitian ini menghasilkan sebuah sistem pendaftaran dan pengelolaan data menggunakan dua jenis bot. Sistem ini memberikan kemudahan dalam proses pendaftaran dan mengefisienkan waktu pembagian kelas serta penyusunan absen dari tiap komisariat.

Sistem ini dibangun menggunakan bahasa pemrograman python dan beberapa library yang disebutkan pada Tabel 2. Penjelasan mengenai arsitektur Telegram bot API terdapat pada Gambar 5. 


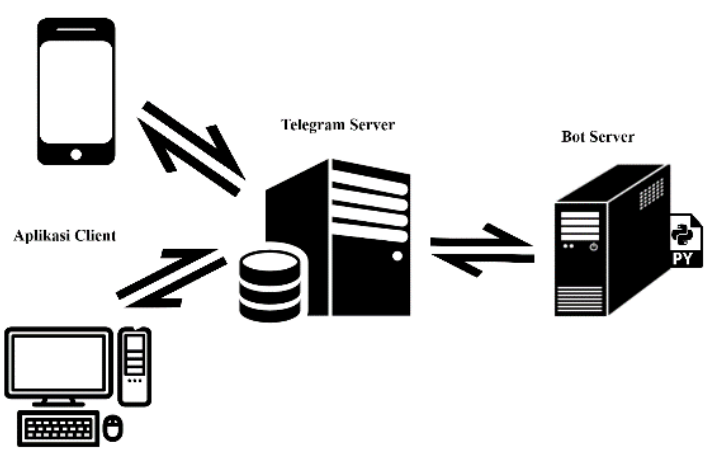

Gambar 6. Arsitektur Telegram Bot

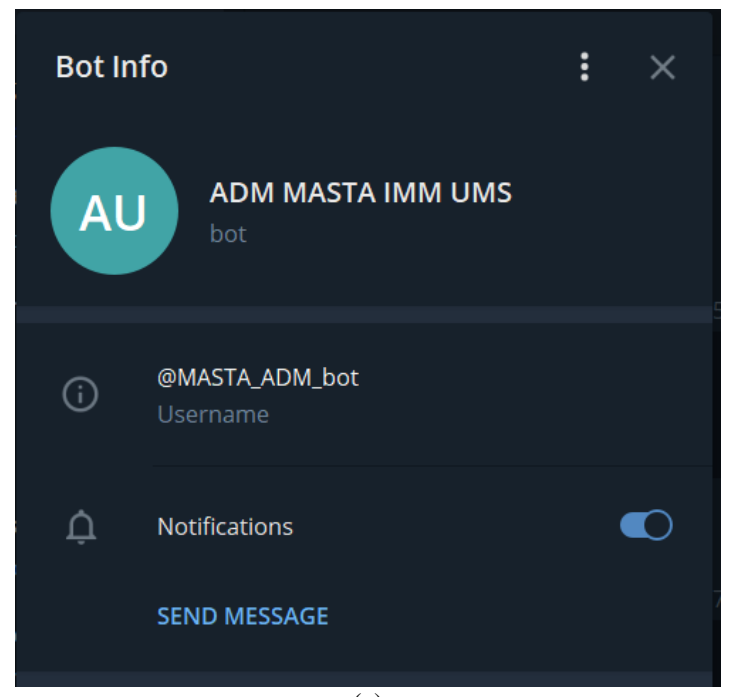

(a)

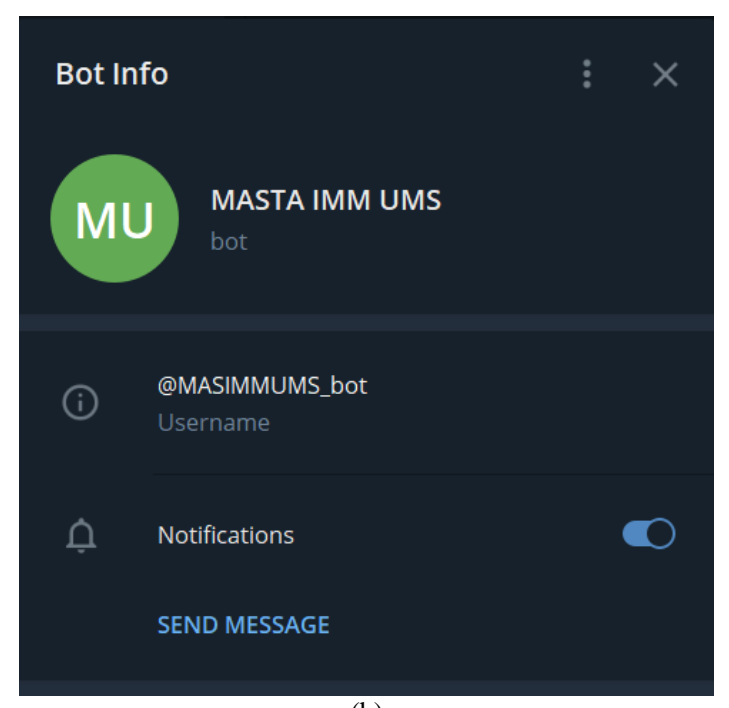

(b)

Gambar 7. (a) Bot Administrasi dan (b) Bot Registrasi

Gambar 6. menjelaskan mengenai cara kerja Telegram bot yang memiliki dua metode untuk berkomunikasi, yaitu Webhooks dan Long Polling yang dapat diakses melalui aplikasi Telegram yang berbasis mobile, desktop ataupun web dan harus terhubung dengan jaringan internet [15]. Proses transaksi data yang terjadi di sini adalah, user akan mengirimkan pesan kepada bot. Pesan tersebut akan diterima oleh Telegram server dan akan diteruskan ke bot server yang telah terhubung dengan Telegram bot API. Kemudian bot server akan memproses pesan tersebut dan akan memberikan balasan kepada user melalui Telegram server [6].

Gambar 7. (a) merupakan bot yang digunakan oleh panitia dan KORKOM dan (b) adalah bot yang digunakan oleh calon peserta MASTA untuk melakukan pendaftaran.

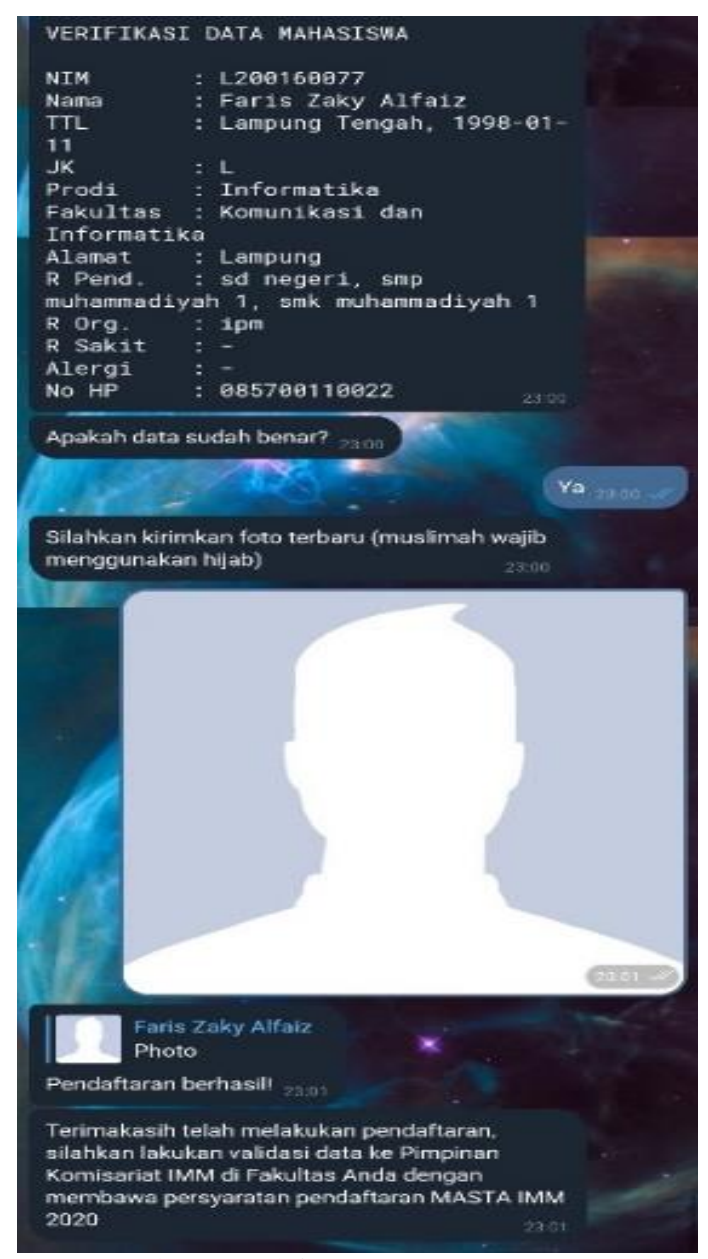

Gambar 8. Pendaftaran peserta MASTA IMM

Gambar 8. menjelaskan proses pendaftaran MASTA IMM yang dilakukan oleh calon peserta menggunakan bot pendaftaran. Calon peserta utamanya adalah mahasiswa baru UMS ataupun mahasiswa tingkat 2 (semester 3) atau lebih yang belum mengikuti MASTA IMM. Calon peserta mengirimkan pesan berupa perintah "/daftarmasta", kemudian pesan tersebut akan diproses dan dijalankan oleh bot server. Selanjutnya user akan diminta mengirimkan data-data yang diperlukan dalam proses pendaftaran. Ketika semua data yang diminta sudah benar, bot server akan menyimpan data tersebut ke dalam database.

Gambar 9. merupakan daftar perintah yang dapat digunakan oleh user yang terdaftar. Gambar 9 (a). berisi perintah yang dapat digunakan oleh KORKOM dan panitia pusat dan Gambar 9 (b). berisi perintah yang dapat digunakan oleh komisariat/panitia lokal. 
Faris Zaky Alfaiz

/daftar_perintah

DAFTAR PERINTAH

/daftar $=>$ untuk mendapatkan izin menggunakan bot ini

KORKOM / PANPUS:

/tambah $=>$ Menambahkan Data

/hapus $\Rightarrow>$ Menghapus Data

$/$ data_peserta $=>$ Melihat jumlah peserta terdaftar

/cetak_data $\Rightarrow>$ Mencetak seluruh data peserta terdaftar

\section{(a)}

\section{| Faris Zaky Alfaiz \\ /daftar_perintah \\ DAFTAR PERINTAH}

\section{KOMISARIAT / PANLOK :}

/validasi $=>$ Memvalidasi peserta

/perbaikan_data $\Rightarrow>$ Mengubah data peserta

/data_peserta $=>$ Meliihat data peserta terdaftar

/bagi_kelas $=>$ Membagi kelas secara otomatis

/cetak_data $\Rightarrow>$ Mencetak data peserta

/cetak_absen => Memcetak absen

(b)

Gambar 9. Daftar Perintah (a) KORKOM dan panitia pusat, (b) komisariat/panitia lokal

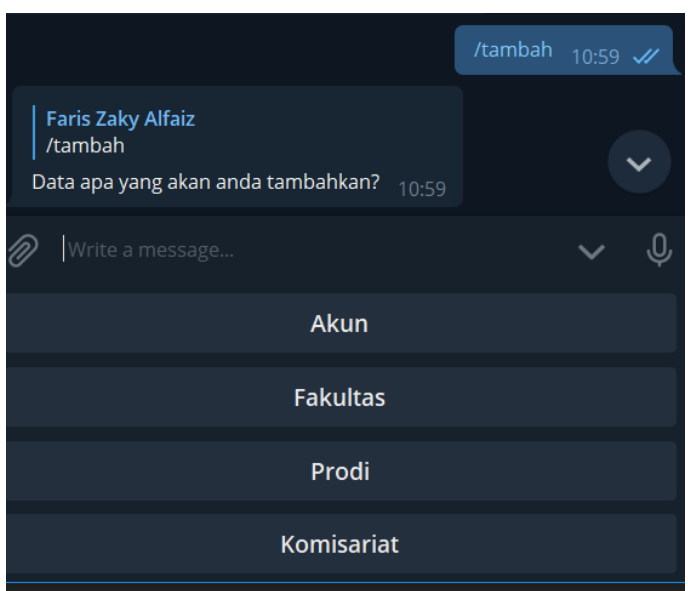

(a)

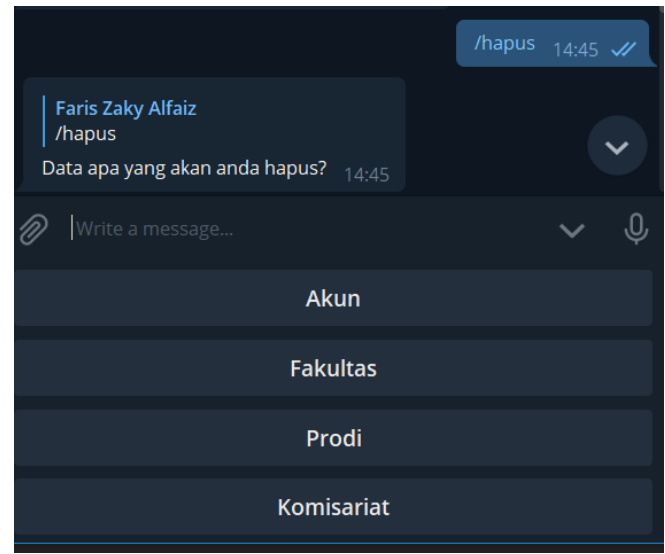

(b)

Gambar 10. (a) Menambahkan data, dan (b) menghapus data
Gambar 10. menjelaskan fungsi (a) penambahan dan (b) penghapusan data meliputi data akun, fakultas, prodi, dan komisariat yang hanya dapat digunakan oleh KORKOM/panitia pusat. Untuk penambahan data, akan ada beberapa masukan yang diminta, bergantung kepada data apa yang akan ditambahkan.

Mahasiswa dengan NIM I200160077 bernama Faris Zaky Alfaiz telah berhasil divalidasi

\section{Gambar 11. Validasi peserta}

Validasi data merupakan fungsi yang hanya dapat digunakan oleh komisariat/panitia lokal. Panitia akan mengirimkan perintah validasi dan kemudian bot akan meminta NIM peserta yang akan divalidasi. Gambar 11. merupakan pemberitahuan jika validasi telah berhasil.

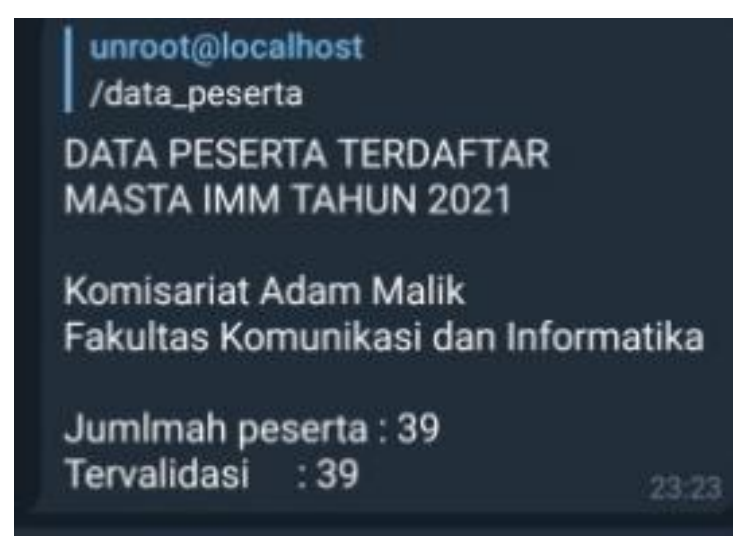

(a)

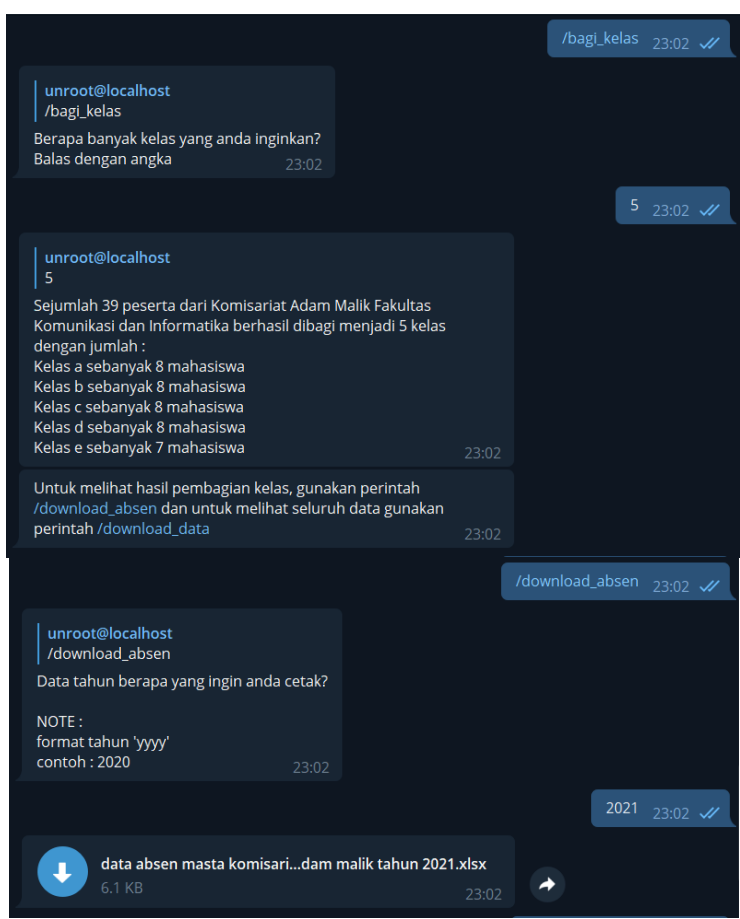

$$
\text { (b) }
$$

Gambar 12. Perintah (a) perkembangan data peserta, dan (b) pembagian kelas dan download absen 
Gambar 12. (a), dan (b) menjelaskan tentang fungsi perintah yang dapat digunakan oleh komisariat/panitia lokal, yaitu "validasi" digunakan untuk melakukan validasi data peserta, "/data_peserta" untuk memantau perkembangan pendaftaran, “/bagi_kelas" untuk melakukan pembagian kelas, dan "/download_absen" untuk melihat hasil pembagian kelas.

\subsection{Pembahasan}

Tahapan ini adalah tahapan pengujian dan evaluasi sistem, metode yang digunakan adalah blackbox testing untuk menguji fungsionalitas system[16] dan System Usability Scale untuk mengevaluasi kegunaan kepada user dengan menggunakan kuesioner [14], [17]. Tabel 3 merupakan hasil dari pengujian blackbox. Pengujian dilakukan oleh pengguna dengan menguji fungsionalitas sistem tanpa mengetahui proses yang terjadi di dalam sistem. Terdapat 2 jenis tester yang melakukan pengujian, yaitu tester admin sebagai komisariat/panitia lokal yang menjalankan bot admin dan tester peserta yang menjalankan bot pendaftaran.

Tabel 3. Blackbox Testing

\begin{tabular}{|c|c|c|c|c|}
\hline BOT & Fitur & Test Case & Hasil yang diharapkan & Hasil \\
\hline Pendaftaran & Cek NIM & $\begin{array}{l}\text { Mengirimkan perintah /cek_nim, dan } \\
\text { selanjutnya NIM }\end{array}$ & $\begin{array}{l}\text { Berhasil melakukan pengecekan } \\
\text { NIM yang dimasukkan atau tidak }\end{array}$ & Valid \\
\hline Pendaftaran & $\begin{array}{l}\text { Daftar } \\
\text { MASTA }\end{array}$ & $\begin{array}{l}\text { Mengirimkan perintah "/daftarmasta" dan } \\
\text { data yang dibutuhkan }\end{array}$ & Berhasil menyimpan data & Valid \\
\hline Pendaftaran & $\begin{array}{l}\text { Contact } \\
\text { Person }\end{array}$ & $\begin{array}{l}\text { Mengirimkan perintah "/contact_person" } \\
\text { dan sistem meberikan balasan berupa data } \\
\text { contact person }\end{array}$ & $\begin{array}{l}\text { Berhasil mengirimkan data ke } \\
\text { user }\end{array}$ & Valid \\
\hline Admin & $\begin{array}{l}\text { Daftar } \\
\text { Admin }\end{array}$ & $\begin{array}{l}\text { Mengirimkan perintah "/daftar", nama, dan } \\
\text { memilih komisariat }\end{array}$ & Berhasil menyimpan data & Valid \\
\hline Admin & $\begin{array}{l}\text { Pengecekan } \\
\text { izin }\end{array}$ & $\begin{array}{l}\text { Sistem akan melakukan pengecekan pada } \\
\text { setiap user yang akan menggunakan } \\
\text { perintah. Jika } \text { user terdaftar dan memiliki } \\
\text { izin, maka bot akan menjalankan perintah } \\
\text { yang dikirimkan. Jika tidak maka sistem } \\
\text { akan mengirimkan pemberitahuan }\end{array}$ & $\begin{array}{l}\text { Berhasil melakukan pengecekan } \\
\text { izin }\end{array}$ & Valid \\
\hline Admin & Validasi & $\begin{array}{l}\text { Mengirimkan perintah "/validasi" dan NIM } \\
\text { peserta yang akan divalidasi }\end{array}$ & $\begin{array}{l}\text { Berhasil mengubah status } \\
\text { validasi }\end{array}$ & Valid \\
\hline Admin & $\begin{array}{l}\text { Perbaikan } \\
\text { Data }\end{array}$ & $\begin{array}{l}\text { Mengirimkan perintah "/perbaikan_data" } \\
\text { dan memasukkan NIM peserta, kemudian } \\
\text { memilih data yang akan diperbaiki }\end{array}$ & $\begin{array}{l}\text { Berhasil menyimpan perubahan } \\
\text { data }\end{array}$ & Valid \\
\hline Admin & Tambah & $\begin{array}{l}\text { Mengirimkan perintah "/tambah" dan } \\
\text { memilih Akun, Fakultas, Program Studi, } \\
\text { atau Komisariat untuk menambahkan data }\end{array}$ & $\begin{array}{l}\text { Berhasil menambahkan dan } \\
\text { menyimpan data Akun, Fakultas, } \\
\text { Program Studi, atau Komisariat }\end{array}$ & Valid \\
\hline Admin & Hapus & $\begin{array}{l}\text { Mengirimkan perintah "/hapus" dan memilih } \\
\text { Akun, Fakultas, Program Studi, atau } \\
\text { Komisariat. Selanjutnya memilih data yang } \\
\text { telah terdaftar pada markup keyboard. }\end{array}$ & $\begin{array}{l}\text { Berhasil menghapus data Akun, } \\
\text { Fakultas, Program Studi, atau } \\
\text { Komisariat }\end{array}$ & Valid \\
\hline Admin & $\begin{array}{l}\text { Data } \\
\text { Peserta }\end{array}$ & $\begin{array}{l}\text { Mengirimkan perintah "/data_peserta" dan } \\
\text { sistem akan mengirimkan data jumlah } \\
\text { peserta terdaftar dan tervalidasi }\end{array}$ & $\begin{array}{l}\text { Berhasil mengirimkan data ke } \\
\text { user }\end{array}$ & Valid \\
\hline Admin & Bagi Kelas & $\begin{array}{l}\text { Mengirimkan perintah "/bagi_kelas" dan } \\
\text { jumlah kelas. Sistem akan melakukan } \\
\text { perhitungan dan pembagian. Hasil } \\
\text { pembagian akan dikonversi ke dalam } \\
\text { dokumen .xlsx sebagai dokumen absen. } \\
\text { Kemudian sistem mengirimkan hasil dari } \\
\text { proses pembagian }\end{array}$ & $\begin{array}{l}\text { Berhasil melakukan pembagian } \\
\text { kelas }\end{array}$ & Valid \\
\hline Admin & $\begin{array}{l}\text { Download } \\
\text { Data }\end{array}$ & $\begin{array}{l}\text { Mengirimkan perintah "/download_data" } \\
\text { dan tahun. Kemudian sistem akan } \\
\text { mengirimkan data peserta dengan format } \\
\text { dokumen .xlsx }\end{array}$ & $\begin{array}{l}\text { Berhasil mengirimkan dokumen } \\
\text { berisi data ke } \text { user }\end{array}$ & Valid \\
\hline Admin & $\begin{array}{l}\text { Download } \\
\text { Absen }\end{array}$ & $\begin{array}{l}\text { Mengirimkan perintah "/download_absen" } \\
\text { dan tahun. Kemudian sistem akan } \\
\text { mengirimkan data peserta dengan format } \\
\text { dokumen .xlsx }\end{array}$ & $\begin{array}{l}\text { Berhasil mengirimkan dokumen } \\
\text { berisi data absen hasil pembagian } \\
\text { kelas ke } \text { user }\end{array}$ & Valid \\
\hline
\end{tabular}

\subsection{Hasil Analisis Kemanfaatan}

System Usability Scale (SUS) adalah metode yang digunakan untuk menguji manfaat dari sistem dengan kuesioner yang di dalamnya terdapat 10 pertanyaan yang memiliki bobot dalam penilaian yang nilainya adalah memberikan skor referensi tunggal untuk pandangan peserta tentang kegunaan produk [18]. SUS adalah standar penilaian kegunaan dari sebuah sistem yang melibatkan user secara langsung [14]. Tabel 4. berisi 10 pertanyaan yang diajukan kepada user. Pengujian ini melibatkan 30 responden yang merupakan mahasiswa UMS. 


\begin{tabular}{clc}
\multicolumn{3}{c}{ Tabel 4. Pertanyaan Kuesioner SUS } \\
\hline No & \multicolumn{1}{c}{ Pertanyaan } & \multicolumn{1}{c}{ Poin } \\
\hline 1 & $\begin{array}{l}\text { Saya berpikir untuk menggunakan sistem ini } \\
\text { kembali. }\end{array}$ & $1-5$ \\
2 & $\begin{array}{l}\text { Saya rasa sistem ini rumit untuk digunakan. } \\
3\end{array}$ & Saya rasa sistem ini mudah digunakan. \\
4 & $\quad$ Saya akan membutuhkan untuk menggunakan \\
& sistem ini. & $1-5$ \\
5 & $\begin{array}{l}\text { Saya rasa fitur yang dimiliki sistem ini } \\
\text { berjalan sesuai dengan semestinya. }\end{array}$ & $1-5$ \\
6 & $\begin{array}{l}\text { Saya merasa ada banyak hal yang tidak } \\
\text { berjalan dengan konsisten pada sistem ini. }\end{array}$ & $1-5$ \\
7 & $\begin{array}{l}\text { Saya merasa orang lain akan mudah } \\
\text { memahami penggunaan sistem ini dengan } \\
\text { cepat. }\end{array}$ & $1-5$ \\
8 & $\begin{array}{l}\text { Saya merasa sistem ini membingungkan. } \\
9\end{array}$ & $\begin{array}{l}\text { Saya merasa tidak ada hambatan dalam } \\
\text { menggunakan sistem ini. }\end{array}$ \\
10 & $\begin{array}{l}\text { Saya perlu membiasakan diri untuk } \\
\text { menggunakan sistem ini. }\end{array}$ & $1-5$ \\
\end{tabular}

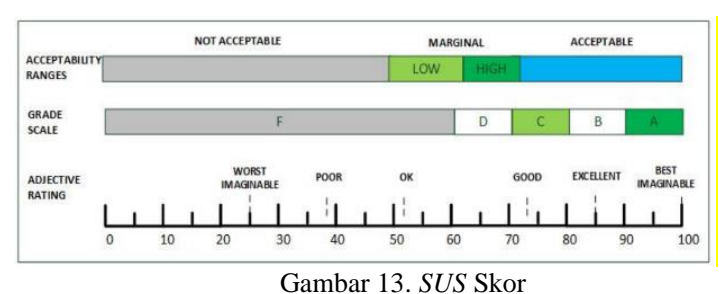

\begin{tabular}{|c|c|c|}
\hline Responden & $\begin{array}{c}\text { Jumla h } \\
\text { Poin }\end{array}$ & Nilai Akhir \\
\hline 1 & 29 & 72,5 \\
\hline 2 & 30 & 75 \\
\hline 3 & 30 & 75 \\
\hline 4 & 32 & 80 \\
\hline 5 & 30 & 75 \\
\hline 6 & 33 & 82,5 \\
\hline 7 & 31 & 77,5 \\
\hline 8 & 30 & 75 \\
\hline 9 & 30 & 75 \\
\hline 10 & 31 & 77,5 \\
\hline 11 & 24 & 60 \\
\hline 12 & 32 & 80 \\
\hline 13 & 29 & 72,5 \\
\hline 14 & 36 & 90 \\
\hline 15 & 30 & 75 \\
\hline 16 & 32 & 80 \\
\hline 17 & 30 & 75 \\
\hline 18 & 31 & 77,5 \\
\hline 19 & 29 & 72,5 \\
\hline 20 & 31 & 77,5 \\
\hline 21 & 29 & 72,5 \\
\hline 22 & 31 & 77,5 \\
\hline 23 & 26 & 65 \\
\hline 24 & 28 & 70 \\
\hline 25 & 30 & 75 \\
\hline 26 & 28 & 70 \\
\hline 27 & 30 & 75 \\
\hline 28 & 23 & 57,5 \\
\hline 29 & 50 & 125 \\
\hline 30 & 31 & 77,5 \\
\hline Nilai Rata-Rata & 30,53 & 76,33 \\
\hline
\end{tabular}

Tabel 5. berisi hasil akhir dari pengujian SUS dengan nilai rata-rata akhir 76,33 yang berarti masuk ke dalam kelompok acceptable dengan didasarkan pada SUS skor pada Gambar 13 [17]. Berdasarkan hasil tersebut, maka Sistem Pendaftaran MASTA IMM UMS Berbasis Chat Menggunakan Telegram bot masuk ke dalam kategori dapat diterima dan dapat digunakan tanpa melakukan perbaikan.

\section{KESIMPULAN}

Sistem ini dirancang untuk memenuhi kebutuhan yang telah ditetapkan sebelumnya dan telah melewati beberapa tahap pengujian, yaitu menggunakan metode blackbox testing dengan hasil sistem dapat berjalan sesuai dengan fungsinya. Kemudian pada pengujian System Usability System (SUS) yang melibatkan 30 orang responden menghasilkan nilai rata-rata akhir 76,33 yang berarti user menyetujui untuk mengimplementasikan sistem ini. Sistem yang telah dirancang dapat dimanfaatkan untuk mempermudah dan meningkatkan efisiensi dalam proses pendaftaran MASTA IMM di UMS. Penelitian ini nantinya dapat dikembangkan lagi dengan menambahkan fitur dan fungsi baru, salah satunya adalah fitur broadcast dengan mengaktifkan notifikasi bagi peserta untuk mendapatkan informasi MASTA IMM.

\section{DAFTAR PUSTAKA}

[1] U. Rahardja, N. Lutfiani, and M. S. Alpansuri, "Pemanfaatan Google Formulir Sebagai Sistem Pendaftaran Anggota Pada Website Aptisi.or.id," Sisfotenika, vol. 8, no. 2, p. 128, 2018, doi: 10.30700/jst.v8i2.401.

[2] L. N. Gunawan, J. Anjarwirawan, and A. Handojo, "Aplikasi Bot Telegram Untuk Media Informasi Perkuliahan Program Studi Informatika-Sistem Informasi Bisnis Universitas Kristen Petra," Jurnal Infra Petra, vol. 6, no. 1, pp. 921-921, 2018, doi: 10.1038/nri2221.

[3] R. Somya, "Perancangan Aplikasi Chatting Berbasis Web di PT. Pura Barutama Kudus menggunakan Socket.IO dan Framework Foundation," Khazanah Informatika: Jurnal Ilmu Komputer dan Informatika, vol. 4, no. 1, p. 8, 2018, doi: 10.23917/khif.v4i1.5979.

[4] R. A. Manna and S. Ghosh, "a Comparative Study Between Telegram and Whatsapp in Respect of Library Services," International Journal of Library and Information Science, vol. 7, no. 2, pp. 1-5, 2018, doi: 10.34218/ijlis.7.2.2018.001.

[5] T. T. Team, "Group Permissions, Undo Delete and More," online, 2019. https://telegram.org/blog/permissionsgroups-undo (accessed Mar. 12, 2020).

[6] G. Sastrawangsa, "Pemanfaatan Telegram Bot Untuk Automatisasi Layanan Dan Informasi Mahasiswa Dalam Konsep Smart Campus," Konferensi Nasional Sistem \& Informatika, pp. 772-776, 2017.

[7] L. Klopfenstein and A. Bogliolo, "the QuizMaster Bot: a Persistent Augmented Quiz 
Delivered Through Online Messaging," INTED2017 Proceedings, vol. 1, pp. 98069811, 2017, doi: 10.21125/inted.2017.2328.

[8] R. D. Risanty and A. Sopiyan, "Pembuatan Aplikasi Kuesioner Evaluasi Belajar Mengajar Menggunakan Bot Telegram Pada Fakultas Teknik Universitas Muhammadiyah Jakarta (Ft-Umj) Dengan Metode Polling.," Jurnal.Umj.Ac.Id/Index.Php/Semnastek, no. November, pp. 1-9, 2017, [Online]. Available:

https://jurnal.umj.ac.id/index.php/semnastek/ article/view/2071/1712.

[9] E. Sudarmilah, H. Supriyono, U. Fadlilah, F. Yasin Al Irsyadi, and A. Fatmawati, "Prototyping AR EduGame for children: Learning Indonesian culture," MATEC Web of Conferences, vol. 197, pp. 1-4, 2018, doi: 10.1051/matecconf/201819703012.

[10] M. Maguire and N. Bevan, "A Review of Supporting Methods," Usability: Gaining a Competitive Edge IFIP World Computer Congress, 2002.

[11] F. Nuriyanti, I. Izzah, M. Azizah, and ..., "Business Process Model Variations in Islamic Boarding Schools Using Requirements Analysis Method," ... Conference on Science ..., vol. 3, no. April, pp. 183-188, 2020, [Online]. Available: http://sunankalijaga.org/prosiding/index.php/ icse/article/view/495.

[12] M. Gultom and Maryam, "Sistem Informasi Penjualan Material Bangunan Pada Toko Bangunan Berkah," Jurnal Teknik Informatika (Jutif), vol. 1, no. 2, pp. 79-86, 2020, [Online]. Available: http://jutif.if.unsoed.ac.id/index.php/jurnal/a rticle/view/19.

[13] P. M. Jacob and M. Prasanna, "A Comparative analysis on Black box testing strategies," Proceedings - 2016 International Conference on Information Science, ICIS 2016, pp. 1-6, 2017, doi: 10.1109/INFOSCI.2016.7845290.

[14] J. R. Lewis and J. Sauro, "Item Benchmarks for the System Usability Scale," Journal of Usability Studies, vol. 13, no. 3, pp. 158-167, 2018, [Online]. Available: https://uxpajournal.org/wp-

content/uploads/sites/8/pdf/JUS_Lewis_May 2018.pdf.

[15] H. Setiaji and I. v. Paputungan, "Design of Telegram Bots for Campus Information Sharing," IOP Conference Series: Materials Science and Engineering, vol. 325, no. 1, 2018, doi: $\quad 10.1088 / 1757-$ $899 X / 325 / 1 / 012005$.

[16] U. al chanani and H. Thamrin, "Pengembangan Sistem Monitoring Layanan Tata Usaha dan Analisis Kemanfaatannya:
Studi Kasus di Fakultas Komunikasi dan Informatika," Proceeding of The URECOL, no. 2, pp. 114-121, 2018.

[17] B. Tujni and F. Syakti, "Implementasi Sistem Usability Scale Dalam Evaluasi Perspektif Pengguna Terhadap Sistem Informasi Akademik Berbasis Mobile," ILKOM Jurnal Ilmiah, vol. 11, no. 3, pp. 241-251, 2019, doi: 10.33096/ilkom.v11i3.479.241-251.

[18] Z. Sharfina and H. B. Santoso, "An Indonesian adaptation of the System Usability Scale (SUS)," 2016 International Conference on Advanced Computer Science and Information Systems, ICACSIS 2016, pp. 145-148, 2017, doi: 10.1109/ICACSIS.2016.7872776. 